\title{
Ambrosiaster se uitleg van die Filemonbrief en die retoriese analise van hierdie brief
}

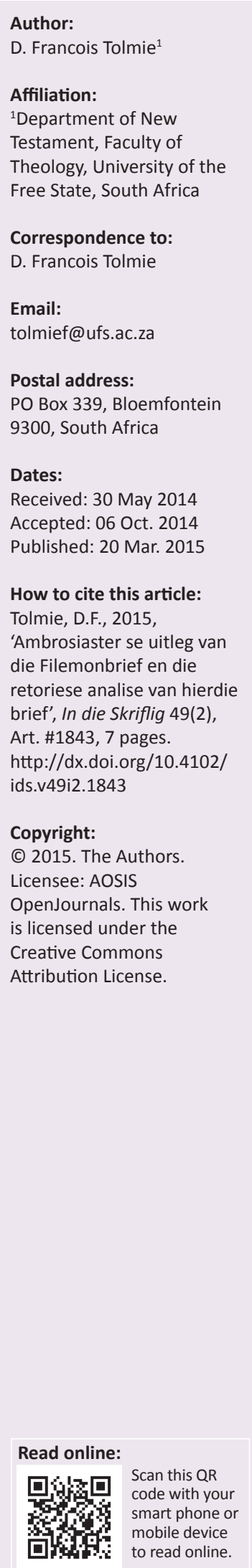

Die studie van Paulus se brief aan Filemon het gebaat by die hernude belangstelling in die retoriese analise van Nuwe-Testamentiese geskrifte, in die sin dat ' $n$ groot aantal retoriese analises van die brief gepubliseer is. Hierdie retoriese analises is vanuit 'n verskeidenheid perspektiewe gedoen, maar tot dusver het niemand nog die manier sistematies ondersoek waarop die vierde-eeuse outeur, wat later die naam Ambrosiaster gekry het, die brief in sy kommentaar op die Pauliniese briewe geïnterpreteer het nie. Hierdie artikel bied dus 'n oorsig van Ambrosiaster se interpretasie van die brief aan Filemon en dui aan watter bydrae dit tot die retoriese analise van die brief kan maak.

Ambrosiaster's exposition of the Letter to Philemon and the rhetorical analysis of the letter. In recent times, the study of Paul's letter to Philemon benefitted from the renewed interest in the rhetorical analysis of New Testament writings, in the sense that a large number of rhetorical studies of the letter have been published. These rhetorical analyses of the letter have been done from different perspectives, but thus far, no one has systematically investigated the way in which the fourth-century author, who was later called Ambrosiaster, interpreted the letter in his commentary on the Pauline letters. Accordingly, this article offers an overview of Ambrosiaster's interpretation of the letter to Philemon, and then outlines the contribution that his reading of the letter can make to the rhetorical interpretation of it.

\section{Inleidend}

Die interpretasie van Nuwe-Testamentiese geskrifte het gebaat by die hernude belangstelling in die retoriese analise die afgelope paar dekades. In die geval van die Filemonbrief het dit tot 'n groot aantal retoriese studies vanuit 'n verskeidenheid perspektiewe gelei. ${ }^{1} \mathrm{Dit}$ is egter opvallend dat daar in sulke retoriese studies van die brief min aandag geskenk word aan die manier waarop die retoriek van die brief in die era van die kerkvaders verstaan is 'n verskynsel wat eintlik vreemd is, aangesien daar heelwat opmerkings oor die retoriese impak van die brief in geskrifte van persone soos Ambrosiaster, Hieronimus, Johannes Chrysostomus, Theodorus van Mopsuestia en ander voorkom. In die lig hiervan is die bedoeling van hierdie artikel om spesifiek op een van hierdie geskrifte te fokus, naamlik die kommentaar wat Ambrosiaster oor hierdie brief geskryf het en dan veral op die manier waarop die retoriese effek van die brief in die kommentaar verstaan word. Die artikel begin met 'n aantal oriënterende opmerkings oor Ambrosiaster - 'n enigmatiese figuur - waarna sy kommentaar op die Filemonbrief ondersoek word, gevolg deur 'n bespreking van die bydrae wat sy interpretasie van die brief tot die retoriese analise van die Filemonbrief sou kon lewer.

\section{Ambrosiaster}

Die kommentaar op die Pauliniese briewe wat hier ter sprake is, is vir meer as 'n duisend jaar aan Ambrosius van Milaan (sterfdatum 397 n.C.) toegeskryf, alhoewel dit in styl en benadering glad nie met Ambrosius se ander werke ooreenstem nie. Daar is eers in die sewentiende eeu besef dat Ambrosius nie die outeur van hierdie werk is nie, en die naam Ambrosiaster is toe geskep vermoedelik deur die Benediktyne wat die kommentaar geredigeer het - vir 'n aanduiding van die onbekende vierde-eeuse Latynse outeur wat vir hierdie kommentaar, asook vir 'n ander

\footnotetext{
1.Slegs enkele voorbeelde hiervan is die volgende: Church (1978:17-33) en Kumitz (2004) volg ' $n$ meer tradisionele benadering waarvolgens die brief as 'n voorbeeld van deliberatiewe retoriek geklassifiseer word en volgens die tradisionele retoriese kategorieë ingedeel word; Wilson (1992:107-119) baseer sy analise op die pragmatiek van Leech; Wansink (1996:64-84) benader die brief vanuit die verskillende wyses waarop Paulus in die brief beskryf word en die bedoelde effek wat dit op Filemon sou gehad het; Russell die verskillende wyses waarop Paulus in die brief beskryf word en die bedoelde effek wat dit op Filemon sou gehad het; Russell
$(1998: 1-25)$ lees die brief as 'n vroeg-Christelike versoekbrief en pas 'n metodologie wat deur Richard Longacre geskep is, daarop toe; Elliott (2011:51-64) skenk spesifiek aandag aan die rol wat takt in Paulus se magspel met Filemon vervul; Snyman (2009:178-193) volg 'n teksgesentreerde retoriese benadering; Lampe (2010:61-78) konsentreer op die retoriese impak wat emosies in die brief gehad het; en Wendland (2010:79-112) benader die retoriek van die brief vanuit' $n$ stilistiese perspektief.
} 
belangrike werk, Quaestiones veteris et novi testamenti, verantwoordelik was. ${ }^{2}$ Die identiteit van die outeur bly ontwykend, ten spyte van talle pogings om dit te bepaal. Die bekendste hiervan is sekerlik die pogings van Morin wat oor 'n tydperk van 30 jaar nie minder nie as vyf verskillende teorieë oor die identiteit van Ambrosiaster die lig laat sien het! ${ }^{3}$ Die feit dat Hieronimus, wat Ambrosiaster se werk geken en daarvan gebruik gemaak het (vgl. Souter 1905:170171), hom nie in sy De viris illustribus noem nie (waarskynlik doelbewus - vgl. Vogels 1966:xv), is 'n jammerte. Wat sake verder bemoeilik, is dat dit voorkom asof die skrywer sy werk van meet af aan anoniem uitgegee het; moontlik 'n doelbewuste keuse om die klem op die Skrif en nie op die eie aansien nie te plaas (aldus Hunter 2009:8, op voetspoor van Souter 1927:40).

Alhoewel Ambrosiaster se identiteit onbekend is, is dit wel moontlik om op grond van sy werk 'n redelike goeie prentjie van hom op te bou: Hy was 'n Romein, moontlik van Spaanse herkoms, het opleiding in die Regte gehad en het waarskynlik op 'n stadium 'n hoë amp in die staatsdiens beklee. Hy het nie in 'n Christelike huis grootgeword nie, maar het eers later tot bekering gekom en mettertyd 'n rol in kerklike sake begin speel. Hy het geleef in die tyd van pous Damasus (366-384 n.C.), van wie hy 'n ondersteuner was (Kannengiesser 2006:1081). Dit wil ook voorkom asof hy 'n kerklike amp beklee het, moontlik dié van presbiter en by een van die groot kerke in Rome betrokke was; dalk een van die kerke buite die mure van die stad (Hunter 2009:15-16).

Kennis van Ambrosiaster kan 'n belangrike bydrae lewer om die kerk in die vierde eeu n.C. beter te verstaan. Dit is die oudste beskikbare Latynse kommentaar op al die Paulusbriewe, ${ }^{4}$ en dit verteenwoordig 'n unieke blik op die kerk in Rome in hierdie tyd. Hunter (2009) vat die perspektief wat Ambrosiaster bied soos volg saam:

Ambrosiaster's significance ... is precisely that he presents a voice that is distinctively clerical, distinctively moderate, and distinctively Roman on many issues of concern in the church at the end of the fourth century. (p. 5)

Die belangrikste temas in Ambrosiaster se werke is die groot klem wat hy op trinitariese en Christologiese aspekte plaas, sy siening van die menslike natuur en die erfsonde, sy kritiek op die heidendom en die Jodedom, asook hulle siening van die wet, en sy siening van die Christelike lewe as 'n lewe van gehoorsaamheid aan God. Hierdie temas is volledig deur

2.Vergelyk Bray (2009:xv-xvi) vir ' $n$ vollediger bespreking hiervan. Dit is voorheen aanvaar dat die naam Ambrosiaster deur Desiderius Erasmus geskep is (vgl. Kannengiesser 2006:1081), maar soos Papsdorf (2013:51, vn. 1) aantoon, word hierdie siening deur onlangse navorsing van Volgers (2005:31) bevraagteken Volgers het die rol wat die Mauriste, 'n Benediktynse groep in Frankryk, in hierdie proses gespeel het, beklemtoon.

3.Vir 'n goeie oorsig van die navorsingsgeskiedenis hiervan, vergelyk Mundle (1919:9-14), Bussières (2007:34-38) en Lunn-Rockliffe (2007:33-43).

4.Daar is wel ander kommentare op die Paulusbriewe beskikbaar wat vroeër as dié van Ambrosiaster geskryf is, maar dit het verlore gegaan, byvoorbeeld dié van Origenes (slegs Rufinus se opsomming van sy uitleg van Romeine is nog beskikbaar). In die geval van die brief aan Filemon word die inhoudelike van Origenes se kommentaar waarskynlik deur Hieronimus weergegee (vgl. Heine 2000:117-133). Marius Victorinus het reeds voor Ambrosiaster sy kommentare op Galasiërs, Marius Victorinus het reeds voor Ambrosiaster sy kommentare op Galasiërs,
Efesiërs en Filippense geskryf, maar dit is nie seker of hy ook nog kommentare op Efesiërs en Filippense geskryf, maar
ander Paulusbriewe geskryf het nie.
Papsdorf (2013:60-74) uitgewerk. Nie een van hierdie temas speel egter 'n groot rol in sy uitleg van die Filemonbrief nie.

Ambrosiaster het sy kommentaar op die Paulusbriewe geskrywe in die tyd toe hy in Rome was, dit wil sê tussen 366 en 384 n.C. ${ }^{5}$ Sy uitleg van die brief is op 'n weergawe van die oud-Latynse teks (die sogenaamde Vetus Latina) gebaseer. $^{6}$ Ambrosiaster kon nie Grieks lees nie en het dit ook nie nodig gevind nie. Hy was byvoorbeeld gekant teen Hieronimus se hersiening van die Latynse vertaling van die Nuwe Testament aan die hand van Griekse tekste, en was vermoedelik een van die 'tweebeen-esels' teen wie Hieronimus uitgevaar het omdat hulle sy poging in hierdie verband gekritiseer het (Hunter 2009:10).

In sy uitleg van Paulus se briewe volg Ambrosiaster min of meer die volgende patroon: Hy begin met 'n kort inleidende gedeelte (argumentum) waarin hy die rede vir die skryf van die brief en die omstandighede waaronder die brief geskryf is, verduidelik. Dan haal hy die Latynse teks stuk vir stuk aan, gevolg deur kort opmerkings waarin hy verduidelik wat Paulus sê. ${ }^{7}$ Hy stel nie eintlik in die grammatikale en stilistiese aspekte van die teks belang nie, vermy enige allegoriese uitleg en fokus primêr op die inhoud (Kannengiesser 2006:1082). Souter (1905) het die toon van Ambrosiaster se kommentaar al meer as 'n eeu gelede soos volg saamgevat:

The work is throughout Roman and practical in tone. Commonsense explanations are the rule. The tone is rather that of the calm dispassionate searcher for truth than of the mystic visionary who seeks to soar to the heights of the Apostle's thought. We have here none of the spiritual insight of an Augustine or a Bengel, but the work of a conscientious writer who seeks in Scripture for plain useful lessons which may serve to elevate the daily lives of his Roman fellow citizens. The author never loses his hold on the ordinary life of the day. The emperor, the magistrates, the laws, etc., ever present to the eyes and minds of his readers, are constantly mentioned in illustration. Yet the work is intended for Christians, and indeed for orthodox Christians. The current heretical errors are from time to time pointed out and stigmatised. Everything written springs from a desire, first, to interpret the Apostle's meaning plainly and naturally, and, secondly, to enforce the lessons he sought to teach. (pp. 6-7)

Sommige van hierdie aspekte is ook sigbaar in sy kommentaar op die Filemonbrief.

Ambrosiaster se kommentaar is twee, of selfs moontlik drie maal hersien, waarskynlik deur homself met die oog op verskillende gehore (Bray 2009:xv), of met die doel om nuwe situasies te verreken (Hunter 2009:9-11). Die beste kritiese teks is die een van H.J. Vogels (1968) in die bekende reeks Corpus Scriptorum Ecclesiasticorum Latinorum (CSEL). Die teksverwysings in hierdie artikel is na hierdie uitgawe,

5.Sommige Ambrosiaster-kenners probeer die ontstaanstyd meer spesifiek aandui, hetsy as die sewentiger- (Bray 2009:16) of tagtigerjare (Hunter 2009:7) van die vierde eeu.

6.Vergelyk Frede (1983:957-958), wat die teks wat Ambrosiaster gebruik het, hoog aanslaan.

7.Vir ' $n$ deeglike bespreking van die formele aspekte van Ambrosiaster se werk, vergelyk Mundle (1919:19-41). 
met 'n verwysing na die bladsynommer, gevolg deur die reëlnommer. David Hunter, Theodore de Bruyn en Stephen Cooper is besig om aan 'n nuwe kritiese teks en 'n Engelse vertaling te werk, maar dit is nog nie gepubliseer nie (Hunter 2009:3). Daar is tans nog net een Engelse vertaling beskikbaar, naamlik deur Gerald L. Bray (2009:161-163) in die Ancient Christian Texts-reeks (ACT).

\section{Ambrosiaster se uitleg van die Filemonbrief}

Argumentum: Ambrosiater begin sy uitleg van die Filemonbrief met die stelling dat Filemon nie enige kerklike amp beklee het nie, maar wel 'n persoon van hoë aansien was (vir laudabilis: CSEL 81/3 337,4). Hy tipeer die brief as 'n persoonlike brief wat deur Paulus ten behoewe van Onesimus, die slaaf van Filemon, geskryf word waarin hy nie net vir Filemon vra om Onesimus terug te verwelkom nie, maar om ook God vir Onesimus te dank omdat hy hom nie net as 'n slaaf nie, maar ook as 'n geliefde broer terugontvang (CSEL 81/3 337,1-7). Hierdie beskrywing is breedweg gebaseer op dit wat Paulus in die brief skryf, veral verse 16 en 17. Die enigste gedagte wat Ambrosiaster hier byvoeg wat nie spesifiek deur Paulus genoem word nie, is dat Filemon God vir Onesimus moet dank.

v. 1-3: Hierdie verse vorm die aanhef van die brief. Ambrosiaster lig die volgende aspekte uit: Paulus noem sy eie swaarkry in die gevangenis om die verhewenheid (dignitas: CSEL 81/3 337,13) van sy skrywe aan te dui. Hy voeg by dat dit skandelik is om 'n gevangene te wees wanneer 'n mens iets verkeerds gedoen het, maar dat dit die hoogtepunt van roem (gloria: CSEL 81/3 337,16) is om ter wille van Christus in die gevangenis te wees. Paulus se verwysing na Filemon as 'n medewerker bring Ambrosiaster in verband met Filemon se toegewydheid; alhoewel Filemon nie ' $n$ kerklike amp beklee het nie, was die behoeftes van die kerk vir hom belangrik omdat hy 'n toegewyde gelowige was. Hieruit neem Ambrosiaster 'n morele les, naamlik dat baie mense soos Filemon waardig is om 'n kerklike amp te beklee, maar dit van die hand wys en juis daardeur toon hoe waardig hulle is (CSEL 81/3 337,8-338,5).

v. 4-6: Wat die danksegging van die brief betref, beklemtoon Ambrosiaster die feit dat Filemon stewig in sy geloof gestaan het en in goeie werke volhard het. Die afleiding wat hy hieruit maak, is dat iemand wat Christus liefhet dit ook toon in die manier waarop hy sy slawe hanteer, wetende dat die Here van hom sal vra wat Filemon van sy eie slawe verwag (CSEL 81/3 338,11-15). Ambrosiaster lig hier 'n implisiete retoriese strategie onderliggend aan die danksegging uit, naamlik dat Paulus deur die manier waarop hy die danksegging verwoord, Filemon daarop attent wil maak dat die Here van hom 'n bepaalde manier van optrede teenoor Onesimus verwag. Ambrosiaster spel dit egter nie verder uit nie. In sy verdere bespreking van hierdie gedeelte fokus hy op die begrip goedheid in V. 6 (bonitas: CSEL 81/3 338,16). Volgens Ambrosiaster vermeld Paulus spesifiek die goedheid van Filemon se werk; dit beteken dat hy op so 'n manier moet optree dat hy in die toekoms ' $\mathrm{n}$ beloning daarvoor kan verwag (CSEL 81/3 338,15-18). Ook in hierdie geval sinspeel Ambrosiaster dus op 'n onderliggende retoriese strategie, naamlik dat Paulus Filemon aanmoedig om voort te gaan om goed te doen. Hy spel dit egter nie volledig uit nie.

v. 7: Hierdie vers, waarin Paulus sy blydskap uitspreek omdat Filemon die harte van die gelowiges verkwik het, word afsonderlik deur Ambrosiaster bespreek. Hy interpreteer Paulus se blydskap as 'n uitdrukking van sy sekerheid dat Filemon positief op sy versoeke in die brief sal reageer, aangesien Paulus belangriker (potior: CSEL 81/3 338,24) is as die mense wat reeds deur Filemon gehelp is (CSEL 81/3 338,21-24). Ambrosiaster interpreteer hierdie vers as 'n retoriese tegniek om druk op Filemon uit te oefen. Aangesien Filemon ander gelowiges gehelp het wat minder aansien as Paulus het, kan hy nie nou weier om vir Paulus, wat baie belangriker as hulle is, te help nie.

v. 8-9: In hierdie verse noem Paulus aan Filemon dat hy aan hom 'n opdrag sou kon gee, maar dat hy ter wille van die liefde eerder ' $n$ beroep op hom doen. In sy uitleg hiervan beklemtoon Ambrosiaster Paulus se apostoliese gesag (apostolica auctoritas: CSEL 81/3 339,1) as meester, op grond waarvan hy sy dissipel 'n opdrag sou kon gee. Volgens Ambrosiaster doen Paulus dit egter nie, aangesien Filemon 'n goeie mens is en Paulus op grond van Filemon se liefde vir hom 'n beroep op hom doen. Ambrosiaster vervolg naamlik dat Filemon omtrent net so oud soos Paulus was en ook 'n gevangene van Jesus Christus is (CSEL 81/3 339,1-3). Hierdie uitleg mag vir mense wat aan die Griekse teks van Filemon gewoond is (waarvolgens Paulus hier na homself verwys) vreemd voorkom, maar dit maak sin indien ' $n$ mens in ag neem dat die Latynse teks wat Ambrosiaster gebruik het, na Filemon verwys. ${ }^{8}$ Getrou aan die teks wat hy tot sy beskikking het, interpreteer Ambrosiaster Paulus se bedoeling soos volg: Paulus vermeld dat hy en Filemon omtrent ewe oud en albei gevangenes van Jesus Christus is. Daarmee sê hy dat daar op Filemon dieselfde verpligting rus om die werk van die Here te doen as wat die ander apostels gedoen het. Ambrosiaster noem dan vir Judas en Silas as voorbeelde van mense wat opgetree het op die wyse soos Paulus van Filemon verwag (CSEL 81/3 339,3-9).

v. 10-14: Hierdie deel bevat Paulus se beroep op Filemon ter wille van sy kind Onesimus, wat Paulus na hom toe terugstuur en wat nou vir Filemon bruikbaar sal wees. Ambrosiaster se uitleg van hierdie verse is baie kort. Hy fokus primêr op Paulus se nederigheid. Dit was besonder prysenswaardig van iemand wat so verhewe (sublimus: CSEL 81/3 339,18) soos Paulus is, om homself te verneder; alhoewel Paulus die reg gehad het om aan Filemon 'n opdrag te gee, versoek hy Filemon om as 'n voorbeeld op te tree met die oog op 'n toename in meriete (ad profectum meritorum: CSEL 81/3 339,21). Ambrosiaster voeg dan verder by dat

8.Die weergawe van die Vetus Latina wat Ambrosiaster gebruik het lui: cum talis sis ... [want jy is dieselfde soort persoon ... ] (CSEL 81/3 338, 27-28). Al die ander Sis ... [want jy is dieselfde soort persoon ... ] (CSEL 81/3 338, 27-28). Al die ander manuskripte van die Vetus Latina lees ook sis ly is], met variasie in woordvolgorde (vgl. Frede 1983:981). Die vertaling in die Vulgaat is ook verkeerd (cum sis talls ... [want jy is dieselfde soort persoon ... ]). Soos Barth en Blanke (2000:320) vermeld, sou 'n korrekte Latynse vertaling gelui het: cum sim talis ... [want ek is so'n persoon ... ]. 
Onesimus 'n vlugteling (profugus: CSEL 81/3 339,21-22) was wat deur Paulus tydens sy gevangenskap in Rome gedoop is. Ambrosiaster beskryf dit op 'n interessante manier, te wete dat Onesimus sy toevlug tot goddelike hulp geneem het (ad divinum auxilium: CSEL 81/3 339,22). Hiermee bedoel Ambrosiaster waarskynlik dat Onesimus vir Paulus beskou het as iemand wat goddelike hulp aan hom kon verleen. Dit is ook moontlik dat Ambrosiaster hier 'n soort asiel in gedagte het. Soos Barth en Blanke (2000:28-30) aantoon, was daar vir vlugtende slawe twee opsies om uit hulle dilemma te kom, naamlik om asiel in die huis van 'n vry persoon te soek, of om asiel by een van die (min) tempels waar slawe asiel kon kry, te soek. Ambrosiaster se stelling dat Onesimus sy toevlug tot goddelike hulp geneem het, sou dalk op 'n manier met die tweede opsie wat Barth en Blanke noem in verband gebring kon word. Dit is egter onseker of Ambrosiaster van hierdie gebruik bewus was, en indien wel, of hy 'n vlug na 'n heidense tempel en Onesimus se vlug na die goddelike hulp wat Paulus kon bied, in dieselfde lig sou beskou het. Dit is ook moontlik dat Ambrosiaster die uitspraak in Deuteronomium 23:15-16 in gedagte gehad het waarvolgens 'n mens nie ' $n$ slaaf wat van sy eienaar ontsnap het, daarheen mag teruggestuur het nie. In Deuteronomium word hierdie aksie van 'n slaaf egter nie spesifiek as 'n vlug na goddelike hulp getipeer nie. Omdat Ambrosiaster so kursories hierna verwys, is dit moeilik om 'n definitiewe keuse te maak. Dit is nietemin opvallend dat Ambrosiaster die feit dat Onesimus na Paulus toe gevlug het, hier op 'n positiewe manier interpreteer. Hy vervolg dat Paulus in Onesimus 'n hoop op bruikbaarheid (utilitatis spes: CSEL 81/3 339,23) raakgesien het, en hom daarom gedoop het. Vervolgens beveel Paulus Onesimus by Filemon aan, aangesien hy in iemand verander is wat in sowel sekulêre as goddelike sake gehoorsaam sal wees (CSEL 81/3 339,17-23).

v. 15-16: In hierdie deel van die brief beklemtoon Paulus dat Onesimus nie net as 'n slaaf na Filemon toe teruggaan nie, maar as ' $n$ geliefde broer, sowel van homself as van Filemon. Ambrosiaster begin sy uitleg deur verder uit te brei op Onesimus se optrede. Onesimus het Filemon gekrenk en ná 'n lang reis by Paulus toevlug gevind. Hy wou wys dat hy na sy vroeëre situasie terugkeer, nie as iemand wat skuldig is nie, maar as iemand wie se sonde uitgewis is. Hy was nou bruikbaar en nie net iemand met net soveel meriete as Filemon nie, maar ook die broer van sy eienaar se leermeester. Volgens Ambrosiaster noem Paulus Onesimus sy broer (sowel in die vlees as in die Here) om daardeur te verhoed dat Filemon Onesimus met hooghartige afkeer behandel soos eienaars geneig is om met hulle slawe te maak. Ambrosiaster gee ook 'n teologiese verduideliking vir Paulus se optrede, naamlik wanneer die menslike situasie buite rekening gelaat word, is ons almal kinders van dieselfde Adam en moet ons mekaar as broers beskou, veral wanneer geloof ter sprake is, omdat dit alle hooghartigheid wegneem (CSEL 81/3 340,1-15).

v. 17: In hierdie vers doen Paulus 'n beroep op Filemon. Indien Filemon Paulus as sy vennoot beskou, moet hy vir Onesimus ontvang soos wat hy vir Paulus sou ontvang het.
In sy uitleg draai Ambrosiaster egter die situasie om, naamlik dat Paulus se liefde vir Onesimus so groot is dat hy sê dat Filemon sy vennoot (particeps: CSEL 81/3 340,18-19) sal word indien hy vir Onesimus ontvang soos wat hy Paulus sou ontvang. Ambrosiaster verbind dit aan 'n uitspraak van Salomo ('n aanhaling uit Sirag 10:25): 'Vry mense sal 'n wyse slaaf dien' (CSEL 81/3 340,16-22). Soos alreeds vroeër deurgeskemer het in Ambrosiaster se interpretasie van v. 15-16, interpreteer hy Paulus se versoek ten opsigte van Onesimus as iets met ingrypende implikasies. Paulus beskou Onesimus naamlik as sy gelyke (sy broer), en omdat Paulus hiërargies hoër as Filemon is, beteken dit dat Filemon per definisie aan Onesimus ondergeskik is: die wyse slaaf wat volgens die uitspraak van Salomo deur Filemon ('n vry man) gedien sal word. Ambrosiaster voeg ook by dat hierdie taktiek van Paulus bedoel is om Filemon die skrik op die lyf te jaag ingeval hy nie bereid sou wees om Onesimus in liefde terug te neem nie (CSEL 81/3 340,21-22).

v. 18: Paulus se aanbod om Filemon te vergoed vir enige skade wat deur Onesimus veroorsaak is, word deur Ambrosiaster geïnterpreteer as 'n poging van Paulus om enige rede vir woede wat Filemon nog kon gehad het, uit die weg te ruim, indien hy so erg deur Onesimus te na gekom is dat hy dit onmoontlik vind om hom te vergewe. Ambrosiaster voeg by dat Paulus vra dat dit op sy rekening sal kom, alhoewel sowel hy as Filemon nou toekomstige erfgename van die koninkryk is, hoewel hulle vroeër sondaars was (CSEL 81/3 340, 23-341,3).

v. 19: In hierdie vers bevestig Paulus met sy eie hand dat hy vir Filemon sal betaal. In sy uitleg hiervan beklemtoon Ambrosiaster dat Paulus bevestig dat die waarborg (cautio: CSEL 81/3 341,6) wat hy namens Onesimus gee, goed genoeg behoort te wees. Ambrosiaster verwys ook na Paulus se woorde dat hy eintlik minder van Filemon vra as wat Filemon hom skuld. Dit beteken dat Filemon in die skuld is by Paulus en dat hy verplig is om daardie skuld terug te betaal deur sy slaaf terug te neem. Ambrosiaster gaan egter nie in op die aard van die skuld nie (CSEL 81/3 341,4-10).

v. 20-21: In hierdie verse meld Paulus dat hy 'n voordeel van Filemon wil geniet, en versoek hy hom om sy hart in Christus te verkwik. Hy spreek ook sy vertroue uit dat Filemon meer sal doen as wat hy vra. Ambrosiaster interpreteer dit soos volg: Paulus hanteer Filemon nou op 'n sagter manier sodat sy gehoorsaamheid vrywillig sal wees, wat vir Paulus ook tot voordeel sal wees. Hy wys ook daarop dat mense gewoonlik meer doen as wat van hulle verwag word indien hulle besef dat iemand 'n hoë dunk van hulle het (CSEL 81/3 341,11-18).

v. 22: Paulus se versoek dat Filemon vir hom 'n gastekamer moet gereedmaak, word deur Ambrosiaster gelees as 'n tegniek om Filemon meer gewillig te maak om Paulus te gehoorsaam. Die rede hiervoor is dat wanneer mense afwesig is, hulle maklik geïgnoreer word. Hy noem ook dat Paulus geen rede gehad het om nie daarheen te gaan nie. Paulus was in elk geval gewoond daaraan om te ly en om slegs in Christus rus te vind. Volgens Ambrosiaster het Paulus ter 
wille van gelowiges gely sodat hulle onverwelklike krone vir die siel en die liggaam kon verwerf. Op hierdie manier is Christus se vyande verwar en God se aansien verhoog (CSEL 81/3 341,19-342,3).

v. 23-25: Ten opsigte van hierdie slotgedeelte van die Filemonbrief maak Ambrosiaster slegs twee opmerkings. Met verwysing na al die persone wat Paulus noem wat ook groete stuur, noem hy net dat Paulus getuig dat hierdie mense almal in sy eer deel. Die eer waarna Ambrosiaster verwys, is waarskynlik die eer wat Paulus ten dele val omdat hy ter wille van Christus in die gevangenis is, soos Ambrosiaster in sy verduideliking in v. 1-3 vermeld het. Verder interpreteer hy die seëngroet ('Die genade van die Here Jesus Christus is met jou gees!') as Paulus se handtekening (subscriptio), wat bevestig dat die brief deur hom gestuur is (CSEL 81/3 342,1-10).

\section{Ambrosiaster en die retoriese analise van die Filemonbrief}

In die lig van die oorsig hierbo word vervolgens op die vraag gefokus hoe Ambrosiaster die retoriek van die brief verstaan het, en of dit enigsins 'n bydrae tot ons verstaan van die retoriek van die brief sou kon lewer. Slegs die belangrikste momente word uitgelig.

Ambrosiaster se verstaan van die retoriese situasie stem breedweg ooreen met wat die tradisionele siening genoem sou kon word en wat die interpretasie van die brief vir 'n lang tyd oorheers het. Hierdie siening was naamlik dat Onesimus 'n wegloopslaaf was wat by Paulus in die gevangenis in Rome uitgekom het waar hy tot bekering gekom het. Hierop het Paulus hom na Filemon, sy eienaar, teruggestuur met die versoek om hom terug te ontvang. Hierdie siening van die retoriese situasie van die brief het die interpretasie van die brief vir ongeveer 1500 jaar oorheers en dit is eers in die vorige eeu deur sommige Nuwe-Testamentici bevraagteken. ${ }^{9}$ Omdat Ambrosiaster se kommentaar op Filemon die oudste kommentaar op die brief is wat behoue gebly het, is dit ook die oudste kommentaar waarin die retoriese situasie op hierdie manier verduidelik word. Dit beteken egter nie dat hy die eerste persoon was wat die situasie sodanig verstaan het nie; dit was waarskynlik toe alreeds 'n siening wat wyd gehuldig is. ${ }^{10}$ Dit is egter wel so dat daar enkele kleiner nuanses is wat deur Ambrosiaster bygevoeg word, byvoorbeeld dat Paulus 'n goeie mens was (v. 8-9); dat Paulus en Filemon ewe oud was en dat Filemon ook 'n gevangene van Christus was (v. 8-9; gebaseer op 'n Latynse teks waarin dit so gestel word). Verder gee hy 'n positiewe interpretasie aan Onesimus se optrede deurdat hy dit as 'n vlug na goddelike hulp beskryf en spesifiek noem dat Paulus hom gedoop het omdat hy in Onesimus hoop op bruikbaarheid gesien het (v. 10-14).

\footnotetext{
9.Vergelyk Tolmie (2009:279-301) vir'n meer volledige oorsig in hierdie verband.
}

10.Dit is moeilik om te bepaal watter bronne Ambrosiaster gebruik het. Vergelyk byvoorbeeld die bespreking hiervan deur Souter (1927:63-65) en Bray (2009:xx-xxi).
Wat Ambrosiaster se interpretasie van Paulus se retoriese strategie in die brief betref, moet vier aspekte uitgelig word.

Die eerste en opvallendste interpretasie is die groot klem wat Ambrosiaster op hiërargiese verhoudings in sy interpretasie laat val. Dat Paulus in 'n gesagsverhouding teenoor Filemon gestaan het, kom telkens ter sprake. Filemon het nie 'n kerklike amp beklee nie (argumentum) ${ }^{11}$ die gelowiges wat deur Filemon gehelp is, het minder aansien as Paulus gehad (v. 7); Paulus het apostoliese gesag gehad (v. 8-9); en hy het die reg gehad om aan Filemon 'n opdrag te gee (v. 10-14). Alhoewel Ambrosiaster een keer in sy kommentaar na die feit verwys dat alle gelowiges gelyk is (v. 15-16), is dit nie die oorheersende moment in die manier waarop hy Paulus se retoriese strategie verstaan nie. Vir hom was Paulus Filemon se meerdere en het hy gesag oor Filemon gehad. Hierdie gedagte speel 'n deurslaggewende rol in sy interpretasie van Paulus se retoriese strategie in die brief. Die interessante aspek hiervan is die logiese uitvloeisel van hierdie vertrekpunt, naamlik dat wanneer Paulus Onesimus sy broer en seun noem, hy eintlik 'n hoër status aan Onesimus toeken as wat Filemon het, omdat Onesimus dan eintlik Paulus se gelyke is. In Ambrosiaster se eie woorde: 'Onesimus is die broer van Filemon se leermeester' (v. 15-16). Ambrosiaster gebruik dus in sy uitleg van v. 17 die aanhaling, 'Vry mense sal 'n wyse slaaf dien', om die nuwe verhouding tussen Onesimus en Filemon aan te dui.

Ambrosiaster se klem op sosiale hiërargie in sy interpretasie van die brief verskil nogal heelwat van die manier waarop die brief deesdae geïnterpreteer word, aangesien Paulus se strategie meestal baie meer egalitêr gelees word. Die volgende twee voorbeelde illustreer dit:

These relationships, of course, flow from the fundamental fact that each of these men [= Paulus, Filemon en Onesimus $]$ has a relationship with Jesus Christ, and this relationship brings them into imitate fellowship as members of a spiritual family ... It is this fellowship built on faith that provides the fundamental theological grounding for Paul's appeal to Philemon. (Moo 2008:398-399)

Um die Rhetorik des Paulus adäquat zu beschreiben, läßt sich in Hinblick auf das aptum von einem aptum der Liebe sprechen.

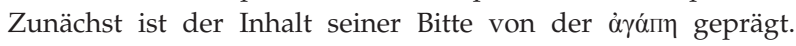

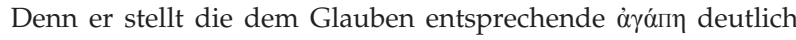
als die seinem Anliegen zugrundeliegende Motivation in der Vordergrund. (Kumitz 2004:214)

Ambrosiaster se interpretasie van hierdie aspek weerspieël waarskynlik die manier waarop kerklike verhoudings in sy tyd gefunksioneer het, ${ }^{12}$ maar dieselfde is dalk ook waar van die groter klem op egalitêre momente in die brief in die moderne uitleg daarvan. Dit is egter ook so dat die situasie waarbinne Ambrosiaster Paulus se brief geïnterpreteer het tot 'n groter mate met die situasie in Paulus se tyd ooreengestem

11.Let op hoe Ambrosiaster se interpretasie hier deur eietydse kerklike strukture beïnvloed word.

12.Vergelyk Papsdorf (2013:57-58) vir 'n goeie oorsig van Ambrosiaster se betrokkenheid by kerklike verhoudings in sy tyd, en hoe hierdie verhoudings gefunksioneer het. 
het. Dit beteken dat sy interpretasie van die situasie deeglike oorweging verdien en miskien selfs as 'n korrektief op die huidige tendense in die interpretasie van die retoriek van die brief kan dien.

Tweedens, wat Ambrosiaster se interpretasie van die detail van Paulus se oorredingstrategie betref, stem dit op ' $n$ hele paar plekke ooreen met die manier waarop dit deesdae verstaan word. ' $n$ Voorbeeld hiervan is Ambrosiaster se interpretasie van v. 22 (Paulus se versoek dat 'n gastekamer vir hom gereed gemaak word) as 'n retoriese strategie om verdere druk op Filemon te plaas. Daar is egter ook 'n paar gevalle waar Ambrosiaster Paulus se retoriese strategie op 'n ander manier verstaan as wat dit gewoonlik deesdae geinterpreteer word. ${ }^{13}$ Uiteraard beteken dit nie dat sy siening noodwendig korrek is nie, maar die retoriese interpretasie van die brief sou net kon baat deur hiervan kennis te neem en dit as 'n alternatiewe interpretasie te oorweeg. Die volgende word spesifiek uitgelig: dat Paulus sy swaarkry in die gevangenis noem met die doel om die verhewenheid van die brief aan te dui (v. 3); die implisiete argument onderliggend aan Paulus se vermelding van Filemon se geloof en goeie werke, naamlik dat iemand wat Christus liefhet dit ook sal wys in die manier waarop hy sy slawe hanteer (v. 4-6); dat Paulus noem dat Filemon ander gelowiges se harte verkwik het om druk op hom uit te oefen (v. 7); en dat Paulus se beroep op Filemon om Onesimus te ontvang soos wat hy vir Paulus sou ontvang, bedoel is om Filemon skrik te maak (v. 17).

'n Derde aspek wat van belang is, is dat Ambrosiaster 'n baie realistiese perspektief het van hoe effektief Paulus se retoriese strategie sou wees. Op 'n hele paar plekke in Ambrosiaster se uitleg skemer dit deur dat hy rekening hou met die moontlikheid dat Filemon dalk nie maklik oortuig sou word nie. Vers 17 word byvoorbeeld as 'n poging van Paulus se kant af beskou om Filemon skrik te maak ingeval laasgenoemde nie bereid sou wees om Onesimus terug te ontvang nie. Nog voorbeelde hiervan is die volgende: in sy uitleg van die twee verse wat v. 17 voorafgaan, noem Ambrosiaster dat Filemon moontlik vir Onesimus op 'n hooghartige manier sou kon hanteer. Verder word v. 18 (Paulus se aanbod om Filemon te vergoed vir die skade wat Onesimus hom dalk aangedoen het) deur Ambrosiaster verstaan as ' $n$ manier om enige rede vir woede by Filemon af te weer, en in v. 22 noem hy dat Paulus aandui dat hy Filemon gaan besoek omdat mense wat afwesig is, maklik geïgnoreer word. Die realisme waarmee Ambrosiaster oor die moontlike sukses van Paulus se brief oordeel, is ook iets waarvan moderne akademici behoort kennis te neem, aangesien daar soms die neiging is om net rekening te hou met 'n moontlike positiewe uitkoms van die brief. Dalk is dit weereens 'n geval dat Ambrosiaster in 'n situasie geleef het wat baie nader aan dié was waarin die brief geskryf is (byvoorbeeld sy eie ervaring van hoe mense in sy tyd oor

13.Die volgende retoriese studies is as basis van vergelyking gebruik: Church (1978:17-33) Wilson (1992:107-119); Wansink (1996:64-84); Russell (1998:1-25); Kumitz (2004); Snyman (2009:178-193); Lampe (2010:61-78); Wendland (2010:79-112) en Elliott (2011:51-64). wegloopslawe gevoel en hulle hanteer het), wat hom noop om ' $n$ meer gepaste evaluering van die moontlike retoriese sukses van die brief te kon gee, of dan ten minste van die weerstand wat by Filemon te wagte kon wees.

Die laaste moment wat uitgelig moet word, is dat Ambrosiaster ' $n$ afwisseling in Paulus se retoriese strategie raaklees wat deur moderne eksegete misgekyk word. Dit gebeur in die laaste gedeelte van die brief waar hy opeenvolgend die volgende strategie uitwys: v. 17 (Paulus se versoek om Onesimus te ontvang soos wat hy, Paulus, ontvang sou word) is gebaseer op 'n skoktaktiek; v. 18 (Paulus se aanbod om Filemon te vergoed) is bedoel om sy woede te ontlont; v. 19 (Paulus se bevestiging dat hy sal betaal) beklemtoon dat Filemon by Paulus in die skuld is; v. 20-21 (Paulus se versoek dat Filemon sy hart sal verkwik) verteenwoordig 'n verandering in toon ('n sagte woord); en v. 22 (Paulus se versoek vir'n gastekamer) is bedoel om druk op Filemon uit te oefen: Paulus kom self kyk hoe Filemon op die brief gereageer het. ' $n$ Mens sou oor die kleiner detail van Ambrosiaster se interpretasie van Paulus se retoriese strategie kon verskil, maar sy aanvoeling vir 'n afwisseling in Paulus se retoriese strategie is 'n belangrike aspek wat met sukses gebruik sou kon word in moderne interpretasies van Paulus se retoriese strategie in die brief.

\section{Ten slotte}

Die doel van hierdie artikel was om 'n oorsig te bied van die manier waarop Paulus se brief aan Filemon in die oudste beskikbare kommentaar op hierdie brief geïnterpreteer is. Afgesien van 'n oorsig van Ambrosiaster se uitleg van die brief is daar ook spesifiek gefokus op die manier waarop hy Paulus se retoriese strategie geïnterpreteer het. Ek vertrou dat ek daarin geslaag het om aan te toon dat moderne interpretasies van die retoriese strategie in die Filemonbrief met vrug kan kennis neem van die manier waarop die brief deur die kerkvaders uitgelê is. Afgesien van Ambrosiaster se interpretasie is daar natuurlik nog verskeie ander sodanige interpretasies uit die era van die kerkvaders wat nog glad nie verreken is nie.

\section{Erkenning}

Dit is ' $n$ voorreg om hierdie artikel aan Prof. Jan A. du Rand, my promotor en voorganger aan die Universiteit van die Vrystaat op te dra. Dit is aan hom te danke dat ek een van die bevoorregtes kan wees wat die Nuwe Testament as loopbaan mag hê! Ek hoop om in hierdie artikel iets te demonstreer wat ek by hom geleer het: Dat dit altyd lonend is om tekste so noukeurig as moontlik te lees.

Finansiële ondersteuning van die NNS (NRF) van SuidAfrika word met dankbaarheid erken.

\section{Mededingende belange}

Die outeur verklaar dat hy geen finansiële of persoonlike verbintenis het met enige party wat hom nadelig of voordelig kon beïnvloed het in die skryf van hierdie artikel nie. 


\section{Literatuurverwysings}

Barth, M. \& Blanke, H., 2000, The letter to Philemon: A new translation with notes and commentary, Eerdmans, Grand Rapids. (Eerdmans Critical Commentary).

Bray, G.L., 2009, Commentaries on Galatians-Philemon: Ambrosiaster, IVP Academic, Downers Grove. (Ancient Christian Texts).

Bussières, M.-P., 2007, Contre les païens (Question sur l'Ancien et le Nouveau Testament 114) et sur le destin (Question sur l'Ancien et le Nouveau Testament 115), Éditions du Cerf, Paris. (Sources Chrétiennes 512).

Church, F.F., 1978, 'Rhetorical structure and design in Paul's letter to Philemon', Harvard Theological Review 71, 17-33. http://dx.doi.org/10.1017/S0017816000025554

CSEL, kyk Vogels.

Elliott, S.S., 2011, 'Thanks, but no thanks': Tact, persuasion, and the negotiation of power in Paul's letter to Philemon', New Testament Studies 57, 51-64. http://dx.doi.org/10.1017/S0028688510000238

Frede, H.J., 1983, Epistula ad Philemonem, Herder, Freiburg. (Vetus Latina 25).

Heine, R.E., 2000, 'In search of Origen's commentary on Philemon', Harvard Theological Review 93, 117-133. http://dx.doi.org/10.1017/S0017816000016734

Hunter, D.G., 2009, '2008 NAPS presidential address: The significance of Ambrosiaster', Journal of Early Christian Studies 17, 1-26. http://dx.doi. org/10.1353/earl.0.0244

Kannengiesser, C., 2006, Handbook of Patristic exegesis: The Bible in ancient Christianity, with special contributions by various scholars, Brill, Leiden.

Kumitz, C., 2004, Der Brief als Medium der áyárn: Eine Untersuchung zur rhetorischen und epistolographischen Gestalt des Philemonbriefes, Peter Lang, Frankfurt am Main. (Europäische Hochschulschriften 787).

Lampe, P., 2010, 'Affects and emotions in the rhetoric of Paul's letter to Philemon: A rhetorical-psychological interpretation', in D.F. Tolmie \& A. Friedl (eds.), Philemon in perspective: Interpreting a Pauline letter, pp. 61-78, De Gruyter, Berlin. (Beihefte zur Zeitschrift für die neutestamentliche Wissenschaft und die Kunde der älteren Kirche 169)

Lunn-Rockliffe, S., 2007, Ambrosiaster's political theology, Oxford University Press, Oxford. (Oxford Early Christian Studies). http://dx.doi.org/10.1093/acprof:0 so/9780199230204.001.0001

Moo, D.J., 2008, The letters to the Colossians and to Philemon, Eerdmans, Grand Rapids. (Pillar New Testament Commentary).
Mundle, W., 1919, Die Exegese der paulinischen Briefe im Kommentar des Ambrosiaster Inaugural-Dissertation zur Erlangung der Licentiatenwürde der Hohen theologischen Fakultät der Universität Marburg, Chr. Schaaf, Marburg.

Papsdorf, J., 2013, "'Ambrosiaster" in Paul and the Middle Ages', in S. Cartwright (ed.), A companion to St. Paul in the Middle Ages, pp. 51-78, Brill, Leiden. (Brill's Companions to the Christian Tradition 39).

Russell, D.M., 1998, 'The strategy of a first-century appeals letter: A discourse reading of Paul's epistle to Philemon', Journal of Translation and Textlinguistics 11, 1-25.

Snyman, A.H., 2009, 'Persuasion in Paul's letter to Philemon', Acta Patristica et Byzantina 20, 178-193.

Souter, A., 1905, A study of Ambrosiaster, Cambridge University Press, Cambridge. (Texts and Studies: Contributions to Biblical and Patristic Literature 7).

Souter, A., 1927, The earliest Latin commentaries on the epistles of St. Paul, Clarendon, Oxford.

Tolmie, D.F., 2009. 'Onesimus - 'n wegloopslaaf? Oor die ontstaansituasie van die Filemonbrief', Verbum et Ecclesia 30(1), 279-301. http://dx.doi.org/10.4102/ ve.v30i1.74

Vogels, H.J., 1966, Ambrosiastri qvi dicitvr commentarivs in epistvlas Pavlinas I: In epistvlam ad Romanos, Hölder-Pichler-Tempsky, Wien. (Corpus Scriptorum Ecclesiasticorum Latinorum [CSEL] 81/1).

Vogels, HJJ, 1968, Ambrosiastri qvi dicitvr commentarivs in epistvlas Pavlinas III: In epistvlas ad Galatas, ad Efesios, ad Filippenses, ad Colosenses, ad Thesalonicenses, ad Timothevm, ad Titvm, ad Filemonem, Hölder-Pichler-Tempsky, Wien. (Corpus Scriptorum Ecclesiasticorum Latinorum [CSEL] 81/3).

Volgers, A.E.C., 2005, 'A church in search of answers: A study of the Latin Quaestionestradition', D.Phil. thesis, Faculty of Humanities, University of Utrecht.

Wansink, C.S., 1996, Chained in Christ: The experience and rhetoric of Paul's imprisonments, Sheffield Academic Press, Sheffield. (Journal for the Study of the New Testament Supplements 130).

Wendland, E., 2010, "'You will do even more than I say": On the rhetorical form of stylistic form in the letter to Philemon', in D.F. Tolmie \& A. Friedl (eds.), Philemon in perspective: Interpreting a Pauline letter, pp. 79-112, De Gruyter, Berlin. (Beihefte perspective: Interpreting a Pauline letter, pp. 79-112, De Gruyter, Berlin. (Beihefte Kirche 169).

Wilson, A., 1992, 'The pragmatics of politeness and Pauline epistolography: A case study of the letter to Philemon', Journal for the Study of the New Testament 48 107-119. http://dx.doi.org/10.1177/0142064X9201504806 